\title{
Political Offense Exceptions to United States Extradition Policy: Aut Dedere Aut Judicare (Either Extradite or Prosecute)
}

\begin{abstract}
Violence is a regrettable and tragic part of mankind and the behavior of our species. But what we cannot eradicate can be reduced and limited. The hope, however, remains that the world community's tolerance for violence may soon reach a level when a change in the values and attitudes of a sufficiently large number of people can cause a change in the policies and practices of states, and also act as a social bulwark against individual and small group terror-violence whether for political or other purposes. Such a change can only be abetted by the respect for and observance of human rights on the part of states and individuals alike. That goal may not easily be achieved, buy try we must if there is to be hope for this civilization to endure. ${ }^{1}$
\end{abstract}

\section{Justification for a New Approach}

When dealing with one accused of a crime who asserts the political offense exception as a defense to extradition, ${ }^{2}$ the United States tends

1. Bassiouni, Legal Responses to International Terrorism [hereinafter LeGal Responses), A Policy-Oriented Inquiry into the Different Forms and Manifestations of 'Intemational Terrorism', xv, liii (Bassiouni ed. 1988).

2. "Extradition is the process by which a person charged with or convicted of a crime under the law of one state is arrested in another state and returned for trial or punishment." Restatement (ThiRd) of the Foreign Relations LAW op the United States [hereinafter Restatzment], $\$ 475$, introductory note (1986). The extradition law of the United States provides that requests for extradition may be granted only pursuant to a treaty. 18 U.S.C. $\$ \$ 3181,3184$ (1988) provides in relevant part:

Whenever there is a treaty or convention for extradition between the United States and any foreign government, any justice or judge of the United States, or any magistrate ... may, upon complaint made under oath, charging any person found within his jurisdiction, with having committed within the jurisdiction of any such foreign government any of the crimes provided for by such treaty or convention, issue his warrant for the apprehension of the person so charged, that he may be brought before such justice, judge or magistrate, to the end that the evidence of criminality may be heard and considered ... If, on such hearing, he deems the evidence sufficient to sustain the charge under the provisions of the proper treaty or convention, he shall certify the same ... to the Secretary of State, that a warrant may issue upon the requisition of the proper authorities 
to wash its judicial hands of the offender. ${ }^{3}$ The political offense exception is a defense to a request for extradition from the United States ${ }^{4}$ and

of such foreign government, for the surrender of such person, according to the stipulations of the treaty or convention; and he shall issue his warrant for the commitment of the person so charged to the proper jail, there to remain until such surrender shall be made.

See also Factor v. Laubenheimer, 290 U.S. 276, 287 (1933); United States v. Rauscher, 119 U.S. 407, 411-12 (1886); Valentine v. United States ex. rel. Neidecker, 299 U.S. 5 (1936) (holding that the executive branch may not exercise discretion to extradite a person unless authority to do so is expressly conferred by treaty); J.M. SWEeney, The International Legal System 141 (3d. 1988) (an extradition treaty entered into by the United States usually contains a list of extraditable offenses).

3. Defining a political act is itself a form of a political act, changing with the nature of the extraditing nation's foreign relations and treaties. By assigning this task in part to the judiciary, the executive branch avoids potential economic repercussions or accusations that it is not diligent in the enforcement of its treaty obligations or that it is interfering in the internal affairs of another nation. See, e.g., Eain v. Wilkes, 641 F.2d 504, 513 (7th Cir. 1981); Note, Bringing the Terrorists to Justice: A Domestic Law Approach, 11 CoRngli INr'z L.J. 71, 74 (1974) (stating that politics need not present a barrier to extradition if executive defers to judiciary).

4. "Under most international agreements, state laws, and state practice: $\mathbf{A}$ person will not be extradited if the offense with which he is charged or of which he has been convicted is a political offense." Restatement, supra note 2, 6 476(2). "The definition of 'political offense' for purposes of extradition has been subject to various understandings in different states and at different times." Id., comment g; "Most definitions of the term 'political offense' are tautologous rather than explanatory since they refer mostly to the political motivation or the political context of the act without defining the element "political, itself." C. Van Den Wijngaert, The Polmtrcal Orfense Exception to Extradition 95 (1980) [hereinafter WijngaERT]. For a discussion of the political offense exception, see Note, Eliminating the Political Offense Exception for Violent Crimes: The Proposed United States-United Kingdom Supplementary Trealy, 26 VA. J. INT'L L. 755 (1986).

Courts distinguish between "pure" and "relative" political offenses. An act is considered a pure political offense if it is directed against the state and involves none of the elements of an ordinary crime. The violence, if any, is minor and rarely involves private victims. Such offenses include treason, sedition and espionage. See, e.g., Ahmad v. Wigen, 726 F. Supp. 389 (E.D.N.Y. 1989); Eain v. Wilkes, 641 F.2d 504, 512 (7th Cir. 1981); Quinn v. Robinson, 783 F.2d 776, 793 (9th Cir. 1986), cert. denied 479 U.S. 882 (1986); "A pure political offense may include acts of prohibited speech, such as speaking against ruling authority, demonstrating peacefully, flag burning or waving and the like." Restatement, supta note 2; pure political offenses are often specifically excluded from the list of extraditable crimes in a treaty. See, e.g., Ahmad v. Wigen, 726 F. Supp. 389; Quinn v. Robinson, 783 F.2d at 794. As well, pure political offenses generally do not provide a basis for extradition because " $[t]$ he purpose of the political offense exception is to protect individual's rights to foster political change through relatively peaceful political activity." Ahmad, 726 F. Supp. at 404.

A relative political offense is an otherwise common crime committed as a political 
its scope has narrowed with the increase of international terrorist activities. Currently, when offenders do escape extradition due to the exception, they are not subject to prosecution by the United States. ${ }^{5}$ Because even violent ${ }^{6}$ offenders may go unprosecuted, courts have a tendency to construe the political offense exception strictly, thereby increasing extradition of those who wish to claim the exception. ${ }^{7}$ As a result, the democratic principles ${ }^{8}$ which the political offense exception was designed to protect are threatened. 9 This Note suggests that the

act or for political motives or in a political context. Id.; "The term 'relative political offense' is at best a descriptive label of doubtful legal accuracy because it purports to alter the nature of the crime committed depending on the actor's motives." BAssioun,, International Extradition 394 (2d ed. 1987) [hereinafter Bassiouni]; for a discussion of the terminology difficulties by the use of the terms "relative," "related," "mixed," "complex" and "connex political offenses," WINJaAerT, supra at 108-110; see also Eain v. Wilkes, 641 F.2d at 512; Quinn v. Robinson, 783 F.2d at 794; BAssiouni, supro at 383; see also Garcia-Mora, The Nature of Political Offenses: $A$ Krotty Problem of Extradition Law 48 VA. L. Rev. 1226, 1239 (1962) (hereinafter Garcia-Mora); Restatement, suppa note 2; The United States Supreme Court has affirmed the notion that relative political offenses are nonextraditable. Gallina v. Fraser, 177 F. Supp. 856 (D. Conn. 1959), aff'd 278 F.2d 77 (2d. Cir.), cert. denied 364 U.S. 851 (1960); most courts require the political motivation to outweigh the intent to commit the common crime in order for a relative political offense to come within the spectrum of the political offense exception. Cantrell, The Political Offense Exemption in Intemational Extradition: A Comparison of the United States, Great Britain and the Republic of Ireland, 60 Marquetre L. Rev. 777, 781 (1977).

5. See, e.g., Doherty v. U.S. Dep't of Justice, Immigration and Naturalization Service, 908 F.2d 1108 (2d Cir. 1990) (granting the right to apply for asylum) (overturning an order issued by the U.S. Attorney General that had denied an attempt by a former Irish Republican Army guerrilla to apply for sanctuary in the United States). Doherty v. Meese, 808 F.2d 938 (2d Gir. 1986); it should be noted that two years later the United States revised the treaty which would have permitted extradition. Supplementary Treaty of Extradition, the United States and the United Kingdom, T.I.A.S. No. 8468, reprinted in 24 I.L.M. 1105 (1985) (hereinafter Supplementary Treaty). Ratified on July 18, 1986, this treaty precludes any claim that a violent political act can be considered a political offense.

6. See infre notes 47-56 and accompanying text for a discussion of the terms "violent" and "terrorism". See also Bassioun,, supra note 4 at 386; International Griminal Law, a Guide to U.S. Practice and Procedure [hereinafter IntrRnational Crtminal Law] 336-342 (V. Nanda \& M. Bassiouni eds. 1987); See also Restatement, supre note $2, \mathrm{~s} 475$, introductory note.

7. See, e.g., In re Doherty, 599 F. Supp. 270 (S.D.N.Y. 1984), aff'd, 786 F.2d 491 (2d. Cir. 1986).

8. See infra notes $36-45$ and accompanying text for a discussion of the democratic principles which relate to the political offense exception.

9. See infra notes $36-45$ and accompanying text for a discussion of how those democratic principles are threatened. 
political offense exception should continue to protect all political offenders against extradition, while arguing that violent political offenders should not, as an alternative, go free without punishment.

When political offenders accused of committing violent acts are found in the United States, they should be prosecuted rather than set free. ${ }^{10}$ "The practical application of internationally proclaimed norms has to be assured by states through their domestic enforcement and implementation systems." 11 Countries must adopt domestic legislation which makes violent acts committed anywhere in the world by those who claim political exceptions to extradition punishable under the domestic laws of the nation in which the accused is found. An adaptation of United States domestic law to an extradite or prosecute policy would not require major changes to United States domestic law. In order for an offense to be extraditable, the requirement of double-criminality must be satisfied. "The modern rule in the U.S., and in most countries, is that the offense constitutes a crime under the jurisprudence of the two legal systems." 12 Treaties which include the possibility of prosecuting political offenders by the nations in which they are found should be negotiated by the United States executive branch. Violent criminals who are not political offenders should continue to be extradited upon request.

There are several models for implementing an extradite or prosecute - policy. One model suggests that international institutions can guide nations in drafting their domestic criminal laws:

The theoretical and practical principles underlying the maxim 'aut dedere aut judicare' could perhaps be formulated in a 'Declaration of Principles on International Cooperation in Penal Matters'. Such a declaration could be drafted either within the general context of the United Nations, or within a more restricted regional framework such as the Council of Europe or the European Communities. This Declaration of Principles could constitute a guideline for further efforts in the field of international cooperation in criminal matters, both on the substantive and procedural level and could possibly lead to a better coordination of the various efforts which are at present simultaneously being undertaken. ${ }^{13}$

10. See infra notes 168-185 and accompanying text for a discussion of jurisdictional defenses in relation to an extradite or prosecute policy.

11. WijngazRT, supta note 4 at 218.

12. Bassiouni, International Griminal Law, Procedure 412 (1986) (hereinafter Procedure).

13. Id. 
Another model suggests that violent political crimes should be prosecuted in an international court. ${ }^{14}$ However, enforcement presents a practical problem to the idea of an international court.

The inability of the world community to reach political consensus on the creation of an international criminal court or on the development of alternative mechanisms that would have the features of a direct enforcement system has led to the furthering of the indirect enforcement system. This explains why an increasing number of conventions dealing with international crimes or multilateral and bilateral conventions relating to transnational and common crimes have adopted the conceptual formula aut dedere aut judicare. ${ }^{15}$

This Note urges United States prosecution of violent political offenders under United States domestic law, guided by international agreements and customary international law. The legislature can extend univeral jurisdiction ${ }^{16}$ to the United States for certain violent acts committed abroad. Under a theory of universal jurisdiction, the United States should prosecute political offenders found in its territory who violate internationally agreed-upon standards of conduct which were designed to protect humanity and which have been codified in United States domestic law. Indeed, "the contemporary trend in the world community is to follow the maxim aut dedere aut iudicare, namely to prosecute or punish."'17

The history of the political offense exception in the United States is one of fluctuation. The Supreme Court has only tangentially touched upon issues with regard to the political offense exception because a denial or grant of extradition is generally not judicially reviewable. ${ }^{18}$

14. Id.

15. Bassiouni, International Griminal Law, Crimes 7 (1986) (hereinafter Crimes).

16. See infra notes 161-178 and accompanying text for a discussion of U.S. universal jurisdiction over violent political offenders.

17. Procedure, supra note 12 at 415.

18. Bassioun, supra note 4 at 591 . "The role of the judiciary in United States practice is conclusive in finding that the exception applies, but is not definitive in its findings that the exception is inapplicable since executive discretion can override such findings." Id. at 402 . "It is error to suppose that every case or controversy which touches foreign relations lies beyond judicial cognizance" and "a court can construe a treaty and may find it provides the answer." Id. at 416. 
Although the judiciary has shouldered the burden of interpretation, ${ }^{19}$ it remains unclear as to what extent the executive and political areas of government should be involved. ${ }^{20}$ Moreover, there are accusations that the political offense exception promotes terrorism because it provides a loophole for terrorists around the world to escape justice. Because categorization of a political offense requires an investigation into the particular facts of the occurrence, the term "political offense" eludes practical definition. ${ }^{21}$ Even if the term were definable, it is doubtful that it could be defined in such a way as to garner international acceptance because each society tolerates different levels of political dissidence. It is precisely when one nation deems the acts of an offender sufficiently "political" as to deny a request for extradition by another

19. Id. at 386. See also Deere, Political Offenses in the Law and Practice of Extradition, 27 Am. J. INT'I L. 247, 250 (1933); Evans, Reflections upon the Political Offense in Int'l Practice 57 AM. J. INT'L L. 1, 15 (1963); Garcia-Mora, The Present Status of Political Offenses in the Law of Extradition and Asylum, 14 U. PITT. L. REv. 371, 37172 (1953); Garcia-Mora, supra note 4 at 1230.

20. WiJngaeRT, supra note 4 , at 100,101 ; the State Department retains a key role in the determination of whether the political offense exception applies. Views from the State Department are explicitly or implicitly taken into acccount. See Eain v. Wilkes, 641 F.2d at 515 (stating "[e]ven though we do not leave sole determination to the Executive branch, we believe its views are entitled to great weight in extradition matters'); see also Demjanjuk v. Petrovsky, 776 F.2d 571, 579 (6th Cir. 1985), cert. denied, 475 U.S. 1016 (1986) (holding that interpretation of treaty language by the Department of State is "entitled to considerable deference"); Charltan v. Kelly, 229 U.S. 447, 468 (1913) (stating that "[a] construction of the treaty by the political department of the government, while not conclusive upon a court, is nevertheless of much weight").

Although most treaties leave the determination of what acts constitute political offenses to the judiciary, some extradition treaties expressly designate the executive branch to make the determination of whether an offense is political. See, e.g., Extradition Treaty, June 24, 1980, United States-Netherlands, art. IV, para. 4, T.I.A.S. No. 10733 (entered into farce Sept. 15, 1983); see generally Bassiouni, Extradition Reform Legislation in the United States: 1981-1983, 17 Akrow L. REv. 495, 502 (1984); "The definition of "political offense' will then, like the cubit, alter with the length of the king's arm." International Criminal Law, supra note 6 at 338; professor Blakesley from the University of the Pacific, McGeorge School of Law argues that removing the issue of what constitutes a political offense from the judiciary poses a greater risk to the constitutional system than the risk that such judicial decisions will promote terrorism. Blakesley, 15 DEN. J. INT'L L. \& PoL'y 109, 119 (1986).

21. At least one scholar suggests that the term is impossible to define. 1 Oppenheim, International Law 707-08 (H. Lauterpacht 8th ed. 1955); See also Bassrouni, supra note 4 at 386; for an historical analysis of the international applications and interpretations of the political offense exception, see Comment, The Political Offense Exception: An Historical Analysis and Model for the Future, 64 TUL. L. R. 1195 (1990). 
nation, that the ambiguity of the term presents itself most vividly. It is clear, however, that there is universal acceptance of the notion that violent offenders, ${ }^{22}$ regardless of political motivations, should not go unpunished. ${ }^{23}$

Although the history of the application of the political offense exception in the United States indicates that offenses of a violent nature should not go unpunished, the solution to such moral conviction has been to extradite political offenders, regardless of the fact that they may otherwise be protected by the political offense exception. ${ }^{24}$ The political offense exception is thus minimized in its effect. Reactionary

22. See infro notes 47-56 and accompanying text for a discussion of violent political offenders and violent terrorists.

23. The international community has attempted to isolate the terrorists because international terrorist activities are sometimes beyond the scope of traditional human dissent or revolution in the quest of liberty. Bassiouni, International Extradition \& World Public Order 416 (1974); Saddy, Intemational Terrorim, Human Rights \& World Ordet, 5 Terrorism 325 (1982); W. Waugh, International Terrorism 21 (1982); Friedlander, Coping with Terrorism: What is to be Done? 5 OHo N.U.L. Rev. 432, 438 (1978).

International treaties are used to contain terrorists threats. See, e.g., G.A. Res. 61, 40 U.N. GAOR Supp. (No. 53), U.N. Doc. A/40/53, at 301 (1985) (General Assembly of the United Nations' recognition of the need of member states to cooperate in combating terrorism through apprehension, extradition and prosecution of terrorists); Council of Europe, European Convention on the Suppression of Terrorism, arts. 1 \& 2, 25 Eur. Y.B. 289, 289-90 (1977), 15 I.L.M. 1272, 1272-73 (1976) (excluding terrorists acts from the political offense exception to treaties between members of the Council of Europe); Protocol Additional to the Geneva Conventions of 12 August, 1949, and Relating Protocol to the Protection of Victims of International Armed Conflicts (hereinafter Protocol I), art. 51(2), adopted June 8, 1977, 16 I.L.M. 1396, 1413, reprinted in L. Henkin, R. Pugh, O. Schachter \& H. Smit, Basic Documents Supplement to "International Law Cases and Materials" 195, 202 (2d ed. 1987) (condemning violence designed to spread terror among civilian populations) (hereinafter Documents Supplement]; Protocol Additional to the Geneva Convention of 12 August, 1949, and Relating to the Protection of Victims of Non-International Armed Conflicts (hereinafter Protocol II), art. 4 (2)(d), 16 I.L.M. 1442, 1444 (1977), reprinted in Documents Supplement, supra, 213, 215; 1984 Act to Combat International Terrorism, Pub. L. No. 98-533, 98 Stat. 2706 (seeking more effective international cooperation in the extradition of all terrorists); Kane, Prosecuting Intemational Terrorists in the Uniled States Courts: Gaining the Jurisdictional Threshold, 12 YALE J. Inr'L L. 294, 295 (1987) (noting the rise in terrorism and need for criminal justice system to adapt to deal with it); Lubet, Extradition Reform: Executive Discretion and Judicial Participation in the Extradition of Political Terrorists, 15 CoRnell INT'L L.J. 247, 291 (1982) (advocating reforms to "ensure that the courts do not extend the protection for the exception to those who practice violence against civilians"').

24. See Ahmad v. Wigen, 726 F. Supp 389. 
abrogation of the political offense exception not only threatens the democratic and humanitarian principles embodied by the exception, but also threatens nonviolent political actors. Such offenders may find the trend toward extraditing political offenders and the stringent application by the United States courts too burdensome and, consequently, will be deterred from action for fear of future extradition. Positive political change initiated by nonviolent political offenders may be stagnated..$^{25}$ Alternatively, a policy of extradite or prosecute ${ }^{26}$ will provide foreign political dissidents with notice that certain forms of behavior will not go unprosecuted by the United States, ${ }^{27}$ while at the same time preserving the integrity of the political offense exception for nonviolent political offenders.

Those accused of crimes may escape extradition via the political offense exception if political acts were committed, or acts that were politically motivated but which appear to be common crimes, or if an accused would be tried for political beliefs rather than for the common crimes which were allegedly committed. ${ }^{28}$ Although most current extradition treaties contain political offense exceptions, ${ }^{29}$ extradition requests for political offenders are usually granted because United States courts are reluctant to inquire into the judicial policies of other nations. ${ }^{30}$ It is counter-intuitive to suggest that American courts should be denied the possibility of inquiring into another nation's judicial integrity, while

25. WiJngaert, supro note 4 at 3.

26. See infra notes 168-185 and accompanying text for a discussion of aut dedere aut judicare (extradite or prosecute).

27. There still may be countries which will choose not to follow a policy of "either extradite or prosecute" and will thus provide potential havens for violent political offenders. However, as the United States aligns its extradition treaties with the language of such a policy, i.e. aut dedere aut judicare, it is conceivable that other nations will reciprocate with similar policies.

28. But see Jimenez v. Aristiguieta, 311 F.2d 547 (5th Cir.), cert. denied, 373 U.S. 914 (1962) (where the former President of Venezuela was sought from the United States for financial crimes and murder). The district court found the murder charge to be non-extraditable under the political offense exception but granted extradition because the financial crimes were not within the exception. Consequently, where multiple charges exist, some of which fall outside of the political offense exception, extradition may be granted unless all charges are related or connected to the political motive. Id.

29. Bassrouni, supra note 4; see, e.g., Extradition Treaty, May 4, 1978, United States-Mexico, art. II, 31 U.S.T. 5059, T.I.A.S. No. 9656 (entered into force Jan. 25, 1980); Extradition Treaty, June 9, 1977, United States-Norway, art. II, 31 U.S.T. 5619, T.I.A.S. No. 9679 (entered into force Mar. 7, 1980); but see Supplementary Treaty, supre note 5.

30. See, e.g., Ahmad v. Wigen, 726 F. Supp. 389 (E.D.N.Y. 1989). 
the same courts must inquire into other nations' political circumstances in order to determine whether the offenses of an accused are protected by the political offense exception. ${ }^{31}$ The issue becomes one of how United States courts can best promote justice at home and on an international level when confronted by a political offender who claims a humanitarian or due process exception to extradition. Nonetheless, it is doubtful that an accused who fails to prove that the crimes committed are worthy of the political offense exception would be able to prove that prosecution for those offenses by the requesting nation may be politically slanted.

Even if the political offender acted against a totalitarian government, the United States should, at the very least, avoid complicity to violent acts against innocent citizens of the world and, at the very most, actively move against those persons who resort to indiscriminate violence. The violent political offender of another country, who may not be a direct threat to the political power of the United States, is a threat to the general peace and well-being of the world..$^{32}$ The issue is not whether the violent offender should be prosecuted. Rather, the issue is where such prosecution will take place and whether those accused of violent political acts should be gauranteed procedural safegards from unfair prosecution. This Note concerns itself with only prosecution by the United States of violent political offenders. Nonviolent political offenders will be guaranteed safe haven, free from prosecution in the United States.

Under an extradite or prosecute policy, it would be the task of the executive branch and the legislature to define what acts would merit prosecution by the United States. Standards developed by international agreement may serve as guidelines in the determining whether offenses

31. See infra notes 116-164 and accompanying text for a discussion of judicial application of the political offense exception. Courts require an uprising and a furtherance by the accused of that uprising in order to gain protection under the political offense exception.

32. See, e.g., Filartiga v. Pena-Irala, 630 F.2d 876, 890 (2d Cir. 1980) (analogizing torturers to pirates, as the enemies of mankind); United States v. Layton, 509 F. Supp. 212, 223 (N.D. Cal. 1981) (determining that terrorism is as much a threat to the international community as piracy), appeal dismissed, $645 \mathrm{~F} .2 \mathrm{~d} 681$ (9th Cir. 1981), cert. denied, 452 U.S. 972 (1981); Murphy, Punishing International Terrorists (1985) [hereinafter Punishinc]; Dinstein, Terrorism and War of Liberation: An Israeli Perspective of the Arab-Istaeli Conflict, International Terrorism and Political Crimes 155, 164 (M. Bassiouni ed. 1975) (" [t]he terrorist has replaced the pirate as the hostis humani gerneris par excellence'). 
should be prosecuted in the United States, due to the nature of their violence. ${ }^{33}$ Although international limitations have been entertained by some United States courts in the treatment of the political offender, ${ }^{34}$ no uniform standard has developed. ${ }^{35}$ Moreover, when courts do rely on international treaties for guidance, they do so merely to determine the extraditability of an accused. Currently, once offenders are determined to have acted in a way that is internationally agreed upon as intolerably violent, they are usually extradited, regardless of their political motivations when the act was committed. Protection under the political offense exception thus ceases to exist.

The solution to the problem of the randomly violent political offender should not include judicial evisceration of the political offense exception, because abandonment of the political offense exception has led to an abandonment of democratic principles. For example, the basic premise that individuals have a "right to resort to political activism to foster political change" 36 dominates the use of the political offense exception. The political offense exception is considered "as a kind of political axiom of the democratic state, from which no derogation is warranted." 37 To reduce the scope of the political offense exception is to inhibit political change. ${ }^{38}$

33. See supra note 23.

34. See, e.g., Ahmad v. Wigen, 726 F. Supp. 389 (the court relied upon the Laws of Armed Conflict as a limitation for acceptable behavior to be tolerated of political offenders).

35. See infra notes 116-164 and accompanying text for a discussion of the divergent standards used in application of the political offense exception.

36. WiJnGaERT, supra note 4, at 102; see also LeGAl Responses, supra note 1 at 181-182. Professor Christopher Pyle isolated the philosophical differences which support the political offense exception:

In the Anglo-American context they reflect a traditional Whig-Tory division over the right of revolution and the obligation of nations to provide asylum to fugitives from foreign political strife. On the Whig side remains the Lockean view that there is a right to revolution, and that the courts of liberal republics should stand neutral towards all sides in foreign rebellions. The way to achieve this neutrality, is for nations and their courts to sheild most political fugitives from extradition to the regimes they have recently fought. On the Tory side is an Hobbesian abhorrence of rebellions and a conservative belief that ideologically similar nations ought to help suppress each other's revolutions.

Id.

37. Wijngaert, supre note 4 at 102. The political offense exception in the United States is used to protect those persons who have "committed themselves to the cause of democracy." Id. at 19, 46; see also In re Gonzalez, 217 F. Supp. 717, 721 n.9 (S.D.N.Y. 1963) (granting extradition because the acts of the accused did not appear to be "blows struck in the cause of freedom against a repressive totalitarian regime").

38. WijNGAERT, supra note 4 at 102. 
The right of political activism causes American courts to examine the infinite tension between the laws of a society and the limits of individual freedom. When dealing with political offenders, courts and legislatures must decide where, if at all, the rights of political activists should end. John Stuart Mill summarized the dilemma when he wrote, "[w]e can never be sure that the opinion we are endeavoring to stifle is a false opinion; and if we were sure, stifling it would be an evil still." 39 Mill was acutely aware that individual liberty was not without boundary: "[t]he sole end for which mankind are warranted, individually or collectively, in interfering with the liberty of action of any of their number, is self-protection. " +0 Prosecution of violent political offenders by the United States will provide a boundary for individual liberty, while respecting the tension between the laws of society and the liberty of the individual. Political offenders will be guaranteed due process and freedom from the political structures against which they rebel, and the peaceful expectations of the world's innocent civilians will be preserved.

More democratic principles put forth in support of the political offense exception are the humanitarian, political neutrality, and domestic order rationales. ${ }^{41}$ Under the humanitarian basis, the United States should deny extradition if the accused would be subject to an unfair trial and punishment in the requesting state. ${ }^{42}$ The political neutrality rationale suggests that governments, and especially their nonpolitical branches, should not intervene in the internal political struggles of other nations by inquiring into the extraditability of a political crime. ${ }^{43}$ The political neutrality theory may be aligned with an extradite or prosecute policy because offenders will not be tried for their political beliefs, but rather, they will be tried for the violent methods used to convey such beliefs. The third rationale suggests that because political crimes are believed to be directed against the domestic public order of the requesting state and because the focus of their attack is thought to be localized, the international public order is unaffected

39. The Encyclopedia of Philosophy, vol. 5, 320 (P. Edwards, ed. 1985) (guoting J.S. Mill, On Liberty, Philosophy of John Stuart Mill 211 (Anschultz 2nd ed. 1953)) (hereinafter J.S. MiLI).

40. Id.

41. Wrjngaert, supro note 4 , at 3 .

42. WiJnGaert, supre note 4 at 100 ("[t]his approach overlooks the fact that the non-recognition of the political character of these ideologies in itself constitutes the taking of a political position').

43. Id. at 3 . 
and thus should not require the participation of other nations through extradition." Because the domestic public order rationale minimizes the global effect of political acts, its premise could undermine justification for universal jurisdiction to prosecute the political criminal in the United States. Nonetheless, acts which violate internationally agreed upon limits for violence do threaten the world public order. ${ }^{45}$ The domestic order rationale, though it preserves the political offense exception, should not be used as justification to escape United States prosecution of heinously violent, but nonetheless political, offenses.

The issue thus becomes a practical one of whether the United States will assimilate violent political acts committed in other countries into its own domestic criminal code. Moral complicity to violent acts would be reduced and the United States would serve as an example to the international community. Ideally, other nations will reciprocate until the violent offenders have no haven in which to escape the consequences of their acts. ${ }^{46}$ An examination of political offenders and the humanitarian concerns which accompany the political offense exception reveals that it is reasonable to expect international acceptance of an extradite or prosecute'policy.

\section{A. The Political Offender and Humanitarian Concerns \\ 1. Violence and the Political Offender}

For purposes of legal definition, the terms "violent", "terrorism", and "innocent civilian" have not been universally defined. " One scholar provided a workable definition of the term "terrorism", which is suitable for the purposes of an extradite or prosecute policy:

44. Id.

45. Punishing, supra note 32.

46. See Bassiouni, Intemational Extradition: A Summany of the Contemporary American Practice and a Proposed Formula, 15 WAYNe L. R. 733, 759 (1969) (noting that "states are motivated by selfish reasons and not globally altruistic concepts" and that an impediment to extradition such as the political offense exception illustrates that nation states are not concerned with a "common interest in the protection against criminal threats directed against societies"). Professor Bassiouni went on to note, "[t]he ideal solution is to elevate extradition from the national or parochial plane to the international or universal level. This would first cause us to examine 'criminality' in a world-wide sense rather than a provincial one." Id. at 760. A policy of extradite or prosecute would place acts of random violence by political offenders on an international level. See infra notes 168-185 and accompanying text for a discussion of the extradite or prosecute policy.

47. Legal Responses, supra note 1 at xxi. (this Note limits its discussion to terrorists acts by individuals). 
Terrorism may thus be defined as an ideologically motivated strategy of internationally proscribed violence designed to inspire terror within a particular segment of a given society in order to achieve a power-outcome or to propagandize a claim or grievance irrespective of whether its perpetrators are acting for and on behalf of themselves or on behalf of a state. ${ }^{48}$

Such a definition does not include acts which are not politically motivated. Under an extradite or prosecute policy, an act must not only meet the above definition of terrorism, but also must be in violation of international norms. ${ }^{49}$

The increase in crimes of a political character ${ }^{30}$ has created a need for more international extradition proceedings. ${ }^{51}$ Not all terrorists are politically motivated, nor are all terrorists indiscriminately violent. ${ }^{52}$ Many terrorists target military installations, and thus minimize potential effects on innocent civilians. ${ }^{53}$ By the same token, not all political offenders resort to violent means. Nonviolent political offenders should be guaranteed protection from extradition because the political offense exception was created to protect such individuals. ${ }^{54}$ Most indiscriminate terrorists acts are, however, politically motivated. ${ }^{55}$ Nonetheless, in an attempt to balance the importance of preserving the political offense

48. Id. at xxiii.

49. Id. (stating that " [t]o be deemed international, acts of terror-violence must contain an international element, be directed against an internationally protected target, or violate an international norm"). See, LzGAl Responses, supra note 1 at xxiv - xxvi for a discussion of international terrorism.

50. Id. at xxvi.

51. International Criminal Law, supra note 6, at 333.

52. For a discussion of modern terrorism, see e.g., Fres.ds, Bringing Terrorists to Justice - The Shifting Sands of the Political Offense Exception, Intrennational Aspects or Criminal Law: Enforcing United States Law in the World Community 15 (R.B. Lillich ed. 1981); Hannay, Intemational Tetrorism and the Political Offense Exception to Extradition, 18 Colum. J. Transnat'z L. 381, $381-82$ (1979); Lubet \& Czackes, The Role of the American Judiciary in the Extradition of Political Terrorists, $71 \mathrm{~J}$. CRIM. LAW AND Criminology 193, 193-95 (1980); see also Extradition Reform of 1981; Hearings on H.R. 5227 Before the Subcomm. on Crime of the House Comm. on the Judiciary, 97th Cong., 2d Sess. 20 (1982).

53. Selective targeting by the violent political offender may make a difference in whether the courts will choose to prosecute because attacks on military installations may not be considered violations of international law. It will be the task of the courts and legislature to determine which acts solicit justification for prosecution.

54. See supra note $\mathbf{4 2}$ and accompanying text for a discussion of the humanitarian rationale of the political offense exception.

55. Legal Responses, supra note 1 at xxvii. 
exception with the promotion of peace and protection of the world's innocent civilians, divergent standards have developed and inconsistent policy has emerged. ${ }^{56}$ Under the proposed solution, political offenders found in the United States who violate internationally-defined violent crimes would be prosecuted by the United States under a universally applicable criminal code.

\section{Deterrence and Rehabilitation}

Political offenders do not have typical criminal motivations and there is a question as to whether their prosecution serves any relevant purpose. Such a question will be better understood with an examination of the political offender within the parameters of United States criminal theory. If the political offender is viewed a priori as anti-social and a hindrance to the world community, a much different approach will be taken, as opposed to if the accused is viewed as altruistic and committed to the general well-being of society. Some political theorists have classified the political offender as "hyper-social" 57 rather than anti-social due to fact that such a person does not act from personal motives, but acts for the benefit of society as a whole. Assuming arguendo that political crimes are reactions against the immorality of rulers, the political offender may be hailed as the innocent party while the political power is viewed as the guilty party. ${ }^{58}$ Indeed, the politically disobedient rise against systems either which are not equipped with the appropriate infrastructure necessary to achieve the political changes desired by the offender, or which suffer from a type of tyranny, where the needs of political offenders go unheeded.

The United States, however, has a tendency not to grant the political offense exception to offenders who attack democratic systems because of conflicting ideologies such as anarchism or communism but grants the exception liberally with respect to crimes committed against totalitarian regimes. ${ }^{59}$ As well, the political offense exception is used by the United States as a tool in which to preserve the political interests

56. See infra notes 116-164 and accompanying text for a discussion of the divergent standards which have emerged.

57. See, e.g., Wijngazrt, supro note 4 at 33 (citing W. A. Bonger, Criminaltty and Economic Conditions 173 (1969)). See also H. D. Thoreau, On the Duty of Civil Disbedience, WALDEn AND "Crvil Disobedience" 230 (Signet 1960) (stating that "[u]nder a government which imprisons any unjustly, the true place for a just man is also a prison").

58. WIJNGAERT, supro note 4 at 33 .

59. Id. 
of the nation on an international level. ${ }^{60}$ Ambiguous messages are sent to foreign political dissidents. On the one hand, the United States may condemn a dictatorship whose politics threaten the United States position in the global balance of power, while on the other hand, the United States may support, politically and economically, a dictatorship which has a proven record of human rights abuses against political offenders, yet which may provide regional security for United States influence in an area. ${ }^{61}$ Absent some prevailing domestic policy against it, political offenders may be extradited to countries which support the United States position in the world but which are guilty of repressing humanity. ${ }^{62}$ The litmus becomes one of world politics, rather than of individual struggle and self-determination. The ambiguity of the situation may contribute to an increase in violence by political offenders because non-extraditable criminal behavior is left undefined and, as a consequence, political-criminals are unable to shape their behavior according to what will be tolerated on an international level. The limits of toleration by the international community are tested with political violence. ${ }^{63}$

One may argue that the practice of listing extraditable crimes in treaties, regardless of political motives, serves sufficient notice to potential political criminals. ${ }^{64}$ To such a contention there are two responses: first, the treaties themselves are embodiments of international political alliances which are constantly changing and; second, the "depolitization" 65 and "exception to the exception" 66 approaches taken by such treaties do not dismiss the fact that the accused committed a political offense. Rather, such approaches merely create tautological legal fiction by placing the offenses outside of the spectrum of the exception. ${ }^{67}$

60. See supra notes 59-63 and accompanying text for a discussion of how the political offense exception is used to further the interests of political powers.

61. Legal Responses, supra note 1 at xlv (stating that "[ $t]$ he real impediment [to an international duty to extradite or prosecute], however, is the difference in ideological values among states, and the political will of governments in carrying out a duty to prosecute or extradite").

62. Id.

63. There has been an increase in international terrorists activities. Id. at xxvi.

64. See Supplementary Treaty, supra note 5 .

65. WiJngnert, supra note 4 at 133 (stating that "[t]he depoliticizing formula excepts certain offenses from political asylum by assuming a priori that they are common crimes').

66. Id. at 134 (stating that "[t]he formula of the exception to the exception explicitly derogates from the political offense exception by providing that 'crime $X$ ', notwithstanding its political character, will always by liable to extradition").

67. Id. There is also an issue as to whether the removal of the duty from the 
Rather than place offenses outside of the boundary of the political offense exception, extradition should be denied. Violent political offenders located in the United States should be prosecuted by the United States, thereby preserving the integrity of the political offense exception. However, whether the accused had notice of the illegality of his acts bears upon issues of deterrence and rehabilitation and there is, consequently, a question as to whether prosecution of the political offender will serve American criminal law goals of deterrence and rehabilitation..$^{68}$ Traditional notions of legality may not apply to the political offender:

[P]olitical offenders, as a result of their ideological motivation, are less deterred than other offenders by the penalty .... it must be noted that it is very difficult if not impossible to resocialize political offenders by means of penitentiary treatment because they are fundamentally opposed to the system. In fact, they consider themselves as a sort of prisoners of war of the system, rather than as persons held responsible for their acts committed in violation of law . . From this perspective, the depolitization and the fictive assimilation of political and common offenders serve no operative purpose. ${ }^{69}$

Glearly, new goals must be adopted by the American criminal justice system in order to deal with political offenders.

The United States must take into account a duty to protect the world against violence. The new goal of the criminal justice system, when dealing with a political offender, must not be so much concerned with deterrence and rehabilitation of the political offender as with the preservation of innocent civilians' peaceful expectations, while at the same time preserving the humanitarian principles of the political offense exception. ${ }^{70}$ While noting that one accused of a politically motivated crime poses special due process concerns to the courts, the issue becomes one of where, rather than if, the violent political offender should be prosecuted.

judiciary to determine what constitutes a political offense is violative of the balance of powers established in the United States. Such an issue is not within the scope of this note. See Blakesely, supra note 20.

68. The term "criminal justice system" is all-inclusive. It includes judicial, legislative and reform institutions.

69. WIJNGAERT, supra note 4 , at 32 .

70. See infra notes 168-185 for a discussion of the extradite or prosecute alternative. 


\section{Due Process}

Because other judicial systems of the world do not parallel that of the United States, it is unreasonable and morally imperialistic, not to mention legally inaccurate, to suggest that no extradition should be allowed to a country which does not recognize the same basic principles of due process as recognized by the United States. ${ }^{71}$ Foreign judicial proceedings may be fair and humane without annexation of American constitutional principles. It cannot be ignored, however, that the politically accused, by virtue of their offenses, may be denied basic juridical rights even in a system which normally affords such. ${ }^{72}$ United States courts must be mindful of the human rights concerns dominating extradition attempts of the political offender. Because of the unique nature of the political offense exception, with its intrinsic and independent humanitarian rationale, due process claims of political offenders must be examined more closely. Issues of due process must be carefully considered, in order to prevent the judicial system from being used as an instrument of injustice. The Eastern District of New York in Ahmad v. Wigen" noted that, "[b]ut neither can another nation use the courts of our country to obtain power over a fugitive intending to deny that person due process. "74 Ahmad had allegedly fire-bombed a civilian bus in the occupied territory and he claimed a political offense exception

71. But see Shapiro v. Ferandina, 355 F.Supp. 563 (S.D.N.Y. 1973), modified on other grounds, 478 F.2d 894 (1973), cert. dismissed, 414 U.S. 884 (1973) (arguing that extradition should be denied to countries which do not honor American due process standards.

72. See, Garcia-Mora, Treason, Sedition and Espionage as Political Offenses Under the Law of Extradition, 26 U. PITT. L. REv. 65, 85 (1964) (arguing that political offenders invoke a hostile atmosphere which makes a fair trial impossible).

Currently, political offenders may escape extradition when they prove that the judicial processes to which they would be subjected will be significantly antipathetical to a court's sense of decency. See, e.g., Gallina v. Fraser, 177 F. Supp 856 (D.C. Conn. 1959), aff d 278 F.2d 77 (2d Cir.), cert. denied, 364 U.S. 851 (1960), reh'g denied, 364 U.S. 906 (1960) (stating that a "federal court's sense of decency" may limit extradition); see also In re Matter of Burt, 737 F.2d 1477, 1486-87 (7th Cir. 1984) (holding that "fundamental conceptions of fair play and decency" and "particularly atrocious procedures or punishments" may be considered by the court); Plaster v. United States, 720 F.2d 340, 348, 354 (4th Cir. 1983) (holding that "individual constitutional rights" must be weighed to determine if extradition would be fundamentally unfair"'); United States ex. rel. Bloomfield v. Gengler, 507 F.2d 925, 928 (2d Cir. 1974), cert. denied, 421 U.S. 1001 (1975) (stating that extradition may be "antipathetic to a federal court's sense of decency").

73. Ahmad v. Wigen, 726 F. Supp. 389 (E.D.N.Y. 1989).

74. Id. at 410 . 
when Isreal sought his extradition from the United States. When an offender such as Ahmad, whose acts were clearly political, seeks to avoid extradition for a violent offense, the United States should have a duty to prosecute, regardless of whether the accused would receive a fair trial by the requesting nation.

Under an extradite or prosecute policy, determination of whether an accused would receive a fair trial by the requesting nation would be made by the courts. Whether courts in the United States should inquire into the judicial procedures of another nation is not novel and will be discussed infra. ${ }^{75}$ Currently, an accused may request a habeas corpus hearing which could lead to the denial of extradition based upon the grounds that a fair trial cannot be guaranteed by the requesting nation. ${ }^{76}$ Additionally, extradition treaties often include certain exceptions based upon whether such extradition may lead to unfair treatment of the accused." Outside of treaty limitations, extradition has been fought in the United States on grounds that the trial in the requesting state will be or was unfair, ${ }^{78}$ that the punishment will be excessive or cruel, ${ }^{79}$ and that the requesting country will be unable or does not intend to protect the requested person from assassination attempts. ${ }^{80}$ Although it rarely rejects a request for extradition of political offenders, the executive branch has the final decision in an extradition matter as to whether to deny extradition on humanitarian grounds. ${ }^{81}$

Ultimately, the issue of due process turns on United States jurisdiction over the offense. In 1901, the Supreme Court held in Neely v. Henke $^{82}$ that even a citizen of the United States will be denied constitutional protection for prosecution of crimes which are committed without jurisdiction of the United States and against the laws of a

75. See infra notes $94-115$ and accompanying text.

76. See Ahmad v. Wigen, 726 F. Supp. 389.

77. See Eain v. Wilkes, 641 F.2d at 513; see also Treaty on Extradition, Jan. 21, 1972, United States-Argentina, art. VIII(c), T.I.A.S. No. 7510; Convention on Extradition, Oct. 24, 1961, United States-Sweden, art. VII, T.I.A.S. 5496 (restricting extradition for a capital offense or requiring the requesting country to ensure that the death penalty is not used); RESTATEMENT, supra note 2, s 475.

78. See Neely v. Henkel, 180 U.S. 109, 122 (1901) (accused arguing that due process rights will not be protected by a Cuban trial).

79. See Escobedo v. United States, 623 F.2d 1098, 1107 (accused arguing that they would be tortured in prison if returned to Mexico).

80. See Sidona v. Grant, 619 F.2d 167, 174 (2d Cir. 1980) (where assassination of the accused was targeted by his political enemies).

81. S. Treaty Doc. No. 100-20, 100th Cong. 2d Sess. 7 (1988).

82. Neely v. Henkel, 180 U.S. 109 (1901). 
foreign country. ${ }^{83}$ Sixty years later, the Court of Appeals for the Second Circuit re-evaluated the precedent established by Neely in the case of Gallina v. Fraser. When Gallina had been convicted in absentia of armed robbery by the government of Italy, he argued that the trial in Italy violated his due process rights. The district court permitted extradition, noting that United States courts do not have the power to inquire into the judicial procedures of another nation. ${ }^{85}$ The court of appeals affirmed but with exception:

The authority that does exist points clearly to the proposition that the conditions under which a fugitive is to be surrendered to a foreign country are to be determined solely by the nonjudicial branches of the government ... We can imagine situations where the relator, upon extradition, would be subject to procedures or punishment so antipathetic to a federal court's sense of decency as to require re-examination of the principle. ${ }^{86}$

Consequently, the ruling in Neely was expanded by Gallina to include a court's sense of decency as the determiner of whether extradition of a political offender should be denied based upon a claim of due process.'

A similar plea to the court's sense of decency was made in 1989 in the case of Ahmad 0 . Wigen. ${ }^{87}$ Mohmoud El-Abed Ahmad sought a writ of habeas corpus to prevent his extradition to Israel to stand trial for allegedly attacking, with firebombs and automatic weapons fire, a passenger bus. Death of the bus driver and serious injury to one of the passengers resulted. The Abu Nidal Organization, ${ }^{88}$ of which Ahmad

83. Id. (where an American citizen charged that U.S.C. Section 3184 violated the Fifth Amendment because it did not secure all of the rights, privileges and immunities gauranteed to defendants in U.S. criminal proceedings to the accused when surrendered to a requesting country); see also Kadish, Methodology and Criteria in Due Process Adjudication, $A$ Suroey and Criticism 66 YAle L.J. 319 (1957) (arguing that the requirement of probable cause in an extradition proceeding guarantees that one will not be extradited contrary to basic American notions of due process).

84. 278 F.2d 77 (2d Cir. 1959); see also Ahmad v. Wigen, 726 F. Supp. at 413 (interpreting the Galline ruling to require a showing the extradition would lead to unconscionable abuse by the requesting nation).

85. Gallina v. Fraser, 177 F. Supp 856 (D. Conn. 1959).

86. Gallina v. Fraser, 278 F.2d 77, 78-79; but see Sidona v. Grant 619 F.2d

167 (which warns against reading the Gallina decision too broadly).

87. Ahmad v. Wigen, 726 F. Supp. 389 (E.D.N.Y.).

88. The aims and objectives of the Abu Nidal Organization were described by Charles E. Allen, a career staff employee of the CIA:

The Abu Nidal Organization opposes any settlement of the Arab-Israeli dispute by diplomatic means, preferring the use of violence to reclaim what 
was a member at the time of the offense, publicly announced its responsibility for the attack. ${ }^{89}$ The court rejected Ahmad's claim that he would not be guaranteed a fair trial in Israel for several reasons: first, although he was convicted in absentia, a condition of his surrender to Israel was a retrial; second, a member from the United States Department of State was to observe the new trial to ensure that Ahmad was given a fair trial and; third, Ahmad did not produce sufficient evidence to support his allegations that he would receive an unfair trial in Israel..$^{90}$ In the Ahmad case, there does not appear to be any reason why the court would be offended by Israel's judicial treatment of the accused after extradition. The district court specifically noted, however, that it was not deciding whether Israel would provide a fair trial; rather, it was deciding whether Ahmad had provided sufficient evidence indicating the contrary..$^{91}$ The court in Ahmad placed an undue evidentiary burden upon the accused. Generally, political offenders leave countries which seek their extradition under adverse conditions. Many times political offenders are of meager economic means, which is after what led to their rebellion in the first place. To place the "unfair trial" burden of proof on such defendants is to place them in precarious legal situations because they, most likely, will not be able to afford to produce witnesses or to afford the litigation costs associated with expensive international discovery and litigation.

It may be argued that the burden of trial would be less on such defendants if they were to be prosecuted by the nation which requests their extradition instead of by the United States. Witnesses are easier to produce and evidence is more readily available to defendants who are tried in the nation where the crime was allegedly committed. Such an argument seems to undermine the idea of an extradite or prosecute policy in the United States: political offenders who committed their acts in another country could not get a fair trial in the United States because defendants would be at an evidentiary disadvantage. Whether they are required to prove that the requesting nation will provide an

it considers to be Arab land lost to the state of Israel. It has conducted some 90 terrorist attacks since its inception in 1974, almost one-half of them since the beginning of 1984 . At least 300 people have died and more than 575 have been wounded in attacks conducted by the Abu Nidal Organization.

In te Extradition of Atta, 706 F. Supp. 1032, 1034 (E.D.N.Y. 1989).

89. Id.

90. Id.

91. Ahmad v. Wigen, 726 F. Supp. 389, $415-416$ (E.D.N.Y. 1989). 
unfair trial or whether they are required to defend themselves against prosecution by the United States, political offenders will shoulder unusual evidentiary burdens. ${ }^{92}$

A superior policy is to prosecute violent political offenders found in the United States under United States domestic law through universal jurisdiction. One may argue that such a policy will encourage violent criminals to flee to the United States in order to avoid the judicial wrath of other countries. However, only offenders who meet the political offense exception requirements ${ }^{93}$ will escape extradition, and the violent offenders will face prosecution by the United States. An extradite or prosecute policy will preserve the political offense exception and avoid the practice of inquiry into the judicial processes of other countries, thereby avoiding any violation of the principles of non-inquiry.

\section{Non-Inquiry}

The principle of non-inquiry is that American courts should not and will not inquire into the judicial processes of other nations. The court in In re Ezeta was the first to develop the rule of non-inquiry in a case which involved a political offender. ${ }^{94}$ The court did not examine the claim made by the extraditable defendant that prosecution by the new San Salvador government was politically motivated, although the defendant, who had been a general under the previous government, led a revolt which resulted in the death of General Francisco Menendez, the president of the pre-revolution government. ${ }^{95}$ Courts continue to follow Ezeta, even when persecution of the accused seems eminent. ${ }^{96}$ The issue of political persecution through prosecution was deferred to the executive branch by the court in Ezeta:

It is not a part of the court proceedings nor of the hearing upon the charge of crime to exercise discretion as to whether the criminal charge is a cloak for political action, nor whether the request is made in good faith. Such matters should be left to the Department of State. ${ }^{97}$

92. For example, if prosecuted by the U.S., offenders may not be afforded 6 th amendment rights of the U.S. Constitution which allows for an accused to confront his accusers and for the compulsory process of witnesses.

93. See infra notes 116-164 and accompanying text for a discussion of the judicial tests used in applying the political offense exception.

94. In re Ezeta, 62 F. 972, 986 (N.D. Cal. 1894).

95. Id.

96. See, e.g., Jimenez v. Aristeguieta, 311 F.2d 547 (5th Cir. 1962); In re Gonzales, 217 F. Supp. 717 (S.D.N.Y. 1963); Eain v. Wilkes, 641 F.2d at 518.

97. In re Lincoln, 228 F. 70, 74 (E.D.N.Y. 1915), quoted in In re Gonzalaz, 217 F. Supp. at 722-23. 
The executive branch, however, rarely refuses to return political offenders. ${ }^{98}$

The rationale behind the non-inquiry rule is that a judicial decision as to the legal integrity of another nation may cause difficulties in foreign relations. ${ }^{99}$ Such a policy is predicated both upon deference to the good judgment of the executive and legislative branches who made the extradition treaties and also upon the idea that the judicial branch should not meddle in foreign political affairs. ${ }^{100}$ In 1910, the Supreme Court determined in the case of Glucksman v. Henkel, "01 "[w]e are bound by the existence of an extradition treaty to assume that the trial will be fair." 102 Allowing the fear of adversely affecting foreign relations to dominate issues of extradition threatens the role of the judiciary in its determination of whether a person may be classified as a political offender in the first place, because some inquiry must be made into the political circumstances of the requesting nation. It is contradictory to allow United States courts, on one hand, to inquire into the political situation of another nation in order to determine whether an accused should be extradited, while, on the other hand, those same courts are denied the opportunity to inquire into the judicial proceedings to which the accused would be subjected if extradition were granted. Inquiry cannot be avoided when deciding whether a political offender should be extradited. It is likely that any decision to deny extradition will create the same results in foreign relations, whether the decision is made by the executive branch or by the courts. However, the executive branch currently has the ultimate power:

The ultimate decision regarding extradition is always made by the Secretary of State or another delegated official. The review is de novo, and the executive branch may consider (or reconsider) issues that were or were not raised in the course of the judicial proceeding. Thus, while a court is bound by the terms of the treaty and by judicial precedent, the executive holds the power to deny extradition on factual, procedural,

98. See Lubet \& Czackes, supra note 46 at 199.

99. Shearer, Extradition in International Law 181, 197-98 (1971); see also Jhirad v. Ferrandina, 536 F.2d 478, 485 (2d Cir), cert. denied, 429 U.S. 833 (1976) ("[s]upervising the integrity of the judicial system of another sovereign nation ... would directly conflict with the principle of comity upon which extradition is based").

100. Shearer, supra note 99.

101. Glucksman v. Henkel, 221 U.S. 508 (1910).

102. Id. at 512 . 
humanitarian, or political grounds, or for any other reason of state. ${ }^{103}$

If the legislature codified violent political acts committed in other countries into the United States domestic criminal laws, the executive branch would be bound to allow prosecution in the United States. Judicial involvement will preserve the balance of power which exists between the judicial and executive branches and it will lessen the chance that fundamental due process rights will be compromised due to geopolitical dynamics.

The district court in the Ahmad extradition proceeding, on a habeas corpus review, recognized the role of the judiciary in assessing whether the accused will likely receive a fair trial. The court stated that, "[i]t does entail an obligation not to extradite people who face procedures or treatment that 'shocks the conscience' of jurists acting under the United States Constitution and within our current legal ethos." ${ }^{104}$ The court noted three safegards against wrongful extradition due to the likelihood of abuse by the requesting state, the most important of which was that the courts, "constituting an independent branch of government and charged with defending the due process rights of all those who appear before them, may grant the accused prisoner a writ of habeas corpus blocking extradition." ${ }^{105}$ The court in Ahmad demonstrated that, even when sensitive foreign relations matters are at issue, the executive branch should not involve courts in unsavory decisions to extradite. ${ }^{106}$ The court asserted a new standard for the concept of non-inquiry:

Despite the fact that the executive branch has a constitutional duty and right to conduct foreign policy, and the legislative and executive branches together have the duty and right to enter into treaties for extradition, the courts are not, and cannot be, a rubber stamp for the other branches of government in the exercise of extradition jurisdiction. They must, under Article III of the Constitution, exercise their independent judgment in a case or controversy to determine the propriety of an individual's extradition. The executive may

103. Lubet, Intemational Criminal Law and the "Ice-Nine" Enror: A Discourse on the Fallacy of Universal Solutions, 28 VA. J. INT'L L. 963, 969 (1988).

104. Ahmad v. Wigen, 726 F. Supp. at 411 (E.D.N.Y. 1989) (citing Rosado v. Civiletti, 621 F.2d 1179, 1195-96 (2d Cir.), cert. denied 449 U.S. 856 (1980)).

105. Id.

106. Id. 
not foreclose the courts from exercising their responsibility to protect the integrity of the judicial process. ${ }^{107}$

Although Ahmad failed to provide clear and convincing evidence of the potential for an unfair trial, ${ }^{108}$ the district court in Ahmad challenged the doctrine of non-inquiry.

Ahmad was affirmed in 1990 by the United States Court of Appeals for the Second Circuit. ${ }^{109}$ The court of appeals disagreed, however, with the district court's position on the issue of non-inquiry, stating that role of the court on an appeal from the denial of habeas corpus is limited to: 1) concern over whether the alleged offense is within the extradition treaty and, 2) whether there is sufficient evidence to support probable cause that the accused is guilty of the offense charged by the requesting nation. ${ }^{110}$ The court of appeals justified its rejection of the district court's inquiry into Israel's probable treatment of Ahmad by relying on traditional American notions of non-inquiry, stating, "[ $t]$ he interests of international comity are ill-served by requiring a foreign nation such as Israel to satisfy a United States district judge concerning the fairness of its laws and the manner in which they are enforced." The criticism of the district court approach, on its face, though concerned with the preservation of international comity, does not lend credence to the district court's attempts to align United States policy with that of the international community. Such an alliance, as made by the district court in Ahmad, is highly rational, in view of the particular humanitarian and due process issues which the political offense exception poses to the entire world.

Indeed, the practice of judicial inquiry has expanded in scope on an international level due to the globalization of human rights concerns. ${ }^{12}$ The European Court of Human Rights of the Council of

107. Id. at 412 (citing Barr v. United States, 819 F.2d 25, 27 n. 2 (2d Cir. 1987).

108. Id. at 413 (examining such issues as reports of torture in Israel, Israeli criminal trial procedure, general facts about Ahmad's situation which might make him succeptable to harsh treatment, prison conditions in Israel, and defendant rights against self-incrimination during interrogation by Israeli officials).

109. Ahmad v. Wigen, 910 F.2d 1063 (2d Cir. 1990).

110. Id.

111. Id. at 1067 (ciling Jhirad v. Ferrandina, 536 F.2d at 484-85).

112. See Cantrell, supra note 4, at 792-94; Samuels, The English Fugitive Offenders Act, 1967, 18 U. Toronto L.J. 198 (1968); O'Higgins, Reform of Intra-Commonwealth Extradition, 1966 CrIm. L. Rev. 361 (1966) (illustrating that the American practice of non-inquiry has not yielded international acceptance. For example, the United Kingdom's Fugitive Offenders Act of 1967 mandates inquiry into a foreign state's judicial procedures before extradition may be granted). 
Europe in Strasbourg recently denied an extradition request made by the United States based upon what the court deemed as potential inhumane treatment. ${ }^{113}$ The European Court established guidelines for a situation when another nation requests extradition of a political offender from the United States:

Inherent in the whole of the Convention is a search for a fair balance between the demands of the general interest of the community and the requirements of the protection of the individual's fundamental rights. As movement about the world becomes easier and crime takes on a larger international dimension, it is increasingly in the interest of all nations that suspected offenders who flee abroad should be brought to justice. Conversely, the establishment of safe havens for fugitives would not only result in danger for the State obliged to harbor the protected person but also tends to undermine the foundations of extradition. These considerations must also be included among the factors to be taken into account in the interpretation and application of the notions of inhuman and degrading treatment or punishment in extradition cases. ${ }^{114}$

The European Court searched for a judicial balance between the protection of the accused's rights and the protection of society.

Such a balance will be found when the United States choses to deny extradition due to the humanitarian principles of the political offense exception and to prosecute violent political offenders under a theory of universal jurisdiction.

There is a need for a new policy because the courts in the United States have developed divergent and sometimes conflicting standards in their determinations of the extraditability of political offenders. ${ }^{115}$

\section{B. Application of the Political Offense Exception}

\section{Lack of a Uniform Application in the United States}

Interpretation of the political offense exception has yielded ambiguous results. American courts have adopted variations of the English

113. Ahmad v. Wigen, 726 F. Supp. 389 (E.D.N.Y. 1989).

114. Id. at 414 (ciling Soering Case, slip sheet, 1 Eur. Comm'n H.R, 161/217 (1989). Soering, a West German citizen, was wanted in Virginia to stand trial for murder. Extradition to the U.S. was denied on the grounds that the long wait for the death penalty constitutes inhumane treatment. The district court reasoned that the Soering decision may be explained in light of the fact that Soering would be tried for the crime in Germany. Id. Such a rationale supports an extradite or prosecute policy.

115. See infra notes 116-164 and accompanying text for a discussion of the divergent standards. 
"incidence test" 116 as put forth in the case of In re Castioni." Castioni killed a resisting member of the incumbent local government during an uprising in the Swiss Canton of Ticino. ${ }^{118}$ The case provides the basic parameters of the incidence test which is two-pronged, requiring an uprising to have existed and a politically motivated act by the accused in furtherance of the uprising:

In order to bring the case within the words of the Act and to exclude extradition for such an act as murder, which is one of the extradition offences, it must at least be shewn [sic] that the act is done in furtherance of, done with the intention of assistance, as a sort of overt act in the course of acting in a political matter, a political rising, or a dispute between two parties in the state as to which is to have the government in its hands, before it can be brought within the meaning of the words used in the Act. ${ }^{119}$

This test has been described by the American courts to mean that the act committed must be "incidental to" 120 an "uprising". ${ }^{121}$

The incidence test was adopted by the United States in 1894 in the case of In re Ezeta. Extradition was granted under the uprising requirement. ${ }^{122}$ The accuseds were charged with arson, robbery and murder ${ }^{123}$ and claimed that extradition should be denied on the grounds

116. See, e.g., Castioni, [1891] 1 Q.B. 149 (1890). The incidence requirement was questioned when, two years after Castioni an anarchist sought refuge in England under the protection of the political offense exception. In the case of In re Meunier, [1894] 2 Q.B. 415, 419 (1892), a distinction was made for the first time between a political struggle for the mastery of a government and activities which are intended to disrupt the social order by affecting private citizenry rather than attempting to take control of a state. Meunier detonated explosives at a French military barracks and at a Paris cafe. The Meunier case is particulary significant because under an "extradite or prosecute" policy, U.S. courts will be expected to distinguish between offenses which are political in nature and those which are randomly violent against innocent civilians.

117. Castioni, supra note 116.

118. Id.

119. Id. at 152.

120. Id.

121. Id.

122. In re Ezeta, 62 F. 972 (N.D. Cal. 1894) (denial of extradition due to the uprising requirement for all but one defendent because his murder was not incidental to the uprising); Cf. Ornelas v. Ruiz, 161 U.S. 502 (1896) (extradition was granted to Mexico when the Supreme court reversed a district court decision and held that there were personal, rather than political motives involved).

123. In re Ezeta, 62 F. at 972. 
that their acts were a result of a revolutionary uprising because they were merely acting to preserve their political positions. ${ }^{124}$ The accused, General Carlos Ezeta, led a revolt against the government but the court held that because an uprising did not exist before the revolt, extradition could not be denied under the uprising requirement. ${ }^{125}$ The court in Ezeta put forth a "chicken-and-egg" inquiry when it required that the uprising precede the revolt. Under such an analysis, none could meet the requirement who begin an uprising, but those who revolt after an uprising has begun would not be extradited. ${ }^{126}$ Such a limitation is arbitrary.

A different limitation was adopted sixty-four years after Ezeta in the case of Karadzole v. Artukovic. ${ }^{127}$ The Yugoslavian government petitioned for extradition of Artukovic because he allegedly had ordered the execution of over 200,000 innocent civilian concentration camp inmates. The Court of Appeals for the Ninth Gircuit affirmed the lower court decision that the offenses were political in nature because they occurred during a time in Croatia when many political factions were struggling for governmental power. ${ }^{128}$ The magistrate on remand found that there was not enough evidence to support probable cause that Artukovic was guilty and Artukovic was not extradited. ${ }^{129}$

124. Id. at 997 .

125. Id.

126. Id.

127. Karadzole v. Artukovic, 247 F.2d 198 (9th Gir. 1957), vacated and remanded per curiam, 355 U.S. 393 (1958); for related proceedings, see Artukovic v. Boyle, 107 F. Supp. 11 (S.D. Cal. 1952), rev'd sub. nom. Ivancevic v. Artukovic, 211 F.2d 565 (9th Cir. 1954), cert. denied, 348 U.S. 818 (1954); United States ex rel. Karadzole v. Artukovic, 170 F. Supp. 383, 393 (S.D. Cal. 1959); see also Lubet \& Czackes, supra note 52 at 203-04 (criticizing the uprising requirment:

It tends to exempt from extradition all crimes occurring during a political disturbance, but not offenses which were not contemporaneous with an uprising ... The over-inclusive aspect of the approach may operate to protect common criminals simply because their crimes occur during times of political disorder).

128. Karadzole, 247 F.2d at 204. It should be noted that the outcome of this decision would be different today under Article VII of the U.S. Genocide Convention Implementation Act of 1987: "The political offense exception may not apply [to acts of genocide]," reprinted in 28 I.L.M. 754 (1989).

129. See Cardozo, When Extradition Fails, Is Abduction the Solution? 55 AM. J. INT'L L. 127 (1961). Judge Cardozo suggested that a refusal of extradition in this case would invite abduction by the requesting state. However, if the U.S. prosecuted offenders, rather than set them free, it would reduce violations of international law by the requesting states in their efforts to gain custody for prosecution. 
The Artukovic decision highlights the inconsistent American approach to the exception because the reason Artukovic was not extradited was due to a lack of probable cause. ${ }^{130}$ The holding by the Ninth Circuit Court of Appeals regarding the uprising requirement thus became irrelevant in terms of the extraditability of Artukovic. Nonetheless, given the court of appeals' analysis, even had there been sufficient probable cause to convict Artukovic, his alleged acts of killing 200,000 innocent civilians would have been protected from extradition by the political offense exception.

\section{Emerging Standards in the Courts Today}

Out of the historical ambiguity, American courts have come forth with divergent standards in their applications of the political offense exception. The three dominant standards which have been applied are the Ninth Circuit's "territoriality and neutrality"131 standard, the Sev-

130. Karadzole, 247 F.2d 198; see also Ramos v. Diaz, 179 F. Supp. 459 (S.D. Fla. 1959) (when Cuba requested extradition of two of Castro's soldiers who had allegedly killed an escaping prisoner after the fall of the Batista government, the Southern District 'Court of Florida found that the acts were in furtherance of a struggle because the victim had been imprisoned as a Batista sympathizer. Because the political offense exception was liberally construed in Ramos, such a decision historically parallels other decisions by American courts); see also Escobedo v. United States, 623 F.2d 1098 (5th Cir. 1979), cert. denied, 449 U.S. 1036 (1980) (when Mexico requested extradition for murder of those in connection with a plan to kidnap the Cuban consul in Mexico, for whom they intended to exchange for Cuban political prisoners. The court held that because the offenses were not incidental to a violent political uprising, the political offense exception would not apply, regardless of political motivations). The key factor in Escobedo became the uprising prong. Because the uprising requirement was narrowly construed, there was no need for the court to investigate whether the accused acted in furtherance of the uprising or whether the accused had political motivations. The case implied that there must be some current uprising already present before a political offense may be claimed. Applying such a rationale to its legal conclusion means that one who starts a political uprising will not be gauranteed the same protection as one who adds to an already existing uprising. There is no legal justification for such a limitation. The seemingly arbitrary limitation placed on the interpretation of the uprising requirement in Escobedo may have turned on the fact that attacks were made upon an innocent person. Additionally, granting a political offense exception such a case would have communicated an undesirable message to international terrorists. It would provide them the freedom to involve persons who are entirely unrelated to the political ends which they seek. What is significant, in terms of the alternative solution of extradite or prosecute, is that the court in Escobedo examined the means of the acts of the political offenders, rather than the circurnstances of those acts, in determining whether to grant or deny extradition.

131. Quinn v. Robinson, 783 F.2d 776 (9th Cir. 1986). 
enth Circuit's "indiscriminate violence limitation" 132 standard, and the Second Circuit's "violation of international law"133 standard. These standards are important to examine, in order to determine what type of a standard should be utilized in future application of the political offense exception under a United States universal jurisdiction extradite or prosecute policy.

\section{a. A Standard of Neutrality}

The Ninth Circuit established a standard of neutrality when England requested extradition of a member of the Provisional Irish Republican Army in Quinn v. Robinson. ${ }^{134}$ Quinn allegedly sent bomb threats to a Roman Catholic bishop, the British Armed Forces, a Crown Court judge, and the Chairman of the Daily Express newspaper. He was also alleged to have killed an off-duty police officer. ${ }^{135}$ The District Court for the Northern District of California granted Quinn the political offense exception because his acts were in furtherance of an uprising, and in 1986 the Court of Appeals for the Ninth Circuit affirmed. ${ }^{136}$ However, Quinn was deemed extraditable by the court of appeals due to a limitation of territoriality placed upon the uprising requirement. ${ }^{137}$

132. Eain v. Wilkes, 641 F.2d 504 (7th Cir. 1981).

133. Ahmad v. Wigen, 726 F. Supp. 389 (E.D.N.Y. 1989); see also Ahmad v. Wigen, 910 F.2d 1063 (2d Cir. 1990).

134. 783 F.2d 776.

135. See supra note 5. Quinn would be extraditable under the Supplementary Treaty.

136. Quinn, 783 F.2d 776; see also McMullen v. INS, 788 F.2d 591 (9th Cir. 1986); McMullen v. INS, 668 F.2d 122 (2d. Gir. 1981) (McMullen was accused of bombing a British army barracks which resulted in the deaths of 13 civilians. The magistrate held that McMullen could escape extradition because his crimes were of a nonextraditable political nature); see McMullen v. INS, 788 F.2d 591 (McMullen was subsequently issued deportation status by the Board of Immigration Appeals of INS because he had committed a "serious nonpolitical crime" under the Immigration and Naturalization Act, 8 U.S.C. s 1253 (h)(2)(C) (1988)).

Deportation of McMullen by INS illustrates the tendency of the United States to rid itself of the violent political offender, in spite of judicial findings. If the United States were operating under an extradite or prosecute policy, McMullen could have been tried in the U.S. for his acts and the tension between the judicial, political, and executive branches would be significantly diminished. See also Matter of Mackin, 80 Cr. Misc. 1 (S.D.N.Y. Aug. 12, 1981), appeal dismissed (by the government), 668 F.2d 122 (2d Cir. 1981).

137. Quinn, 783 F.2d at 807-806 (9th Cir. 1986) (requiring that the offense occur in the accused's own country where the political changed desired by the accused was sought).

The court in Quinn was attempting to preserve the integrity of the political offense 
The furtherance element, as applied in Quinn, did not distinguish between civilian and military targets. It was the court's responsibility to determine whether the conduct was intended to benefit the uprising, rather than to determine the worthiness of the insurgent's cause. ${ }^{138}$ The court of appeals proposed a neutral standard:

It is not our place to impose our notions of civilized strife on people who are seeking to overthrow the regimes in control of their countries in contexts and circumstances that we have not experienced, and with which we can identify only with the greatest difficulty. It is the fact that the insurgents are seeking to change their governments that makes the political offense exception applicable, not their reasons for wishing to do so or the nature of the acts by which they hope to accomplish that goal. ${ }^{139}$

A standard of neutrality best justifies a refusal of extradition due to the political offense exception. Rather than inquire into the validity of an actor's political purposes, the superior policy is to inquire into whether the means used by the political offender were an affront to humanity. If so, extradition should still be denied under the rationale of the neutrality standard but prosecution should be instituted by the United States. The political offense exception will be preserved, as will the peaceful expectations of the world's innocent civilians.

\section{b. Indiscriminate Violence Limitation}

In 1981 the Seventh Circuit added to the political offense exception in Eain v. Wilkes. ${ }^{140}$ The District Court for the Northern District of Illinois granted Israel's request for extradition of a Palestinian who

exception. Ironically, in so doing, the court was forced to create a legal fiction with the notion of territoriality limits on the uprising requirement. The Quinn analysis would not fare well in a situation involving territorial disputes, such as in the occupied territory of Isreal, as no Palestinian refugee could meet the test, by definition. The court's concern that it was the extra-national terrorist who "interfered with the rights of others to exist peacefully under their chosen form of government" is a concern which would hold true for both domestic and extra-national terrorists. Id. It may, however, be the act of labeling a citizen as an extra-nationalist which is at the center of the controversy which led to terrorist acts in the first place. See, e.g., Ahmad v. Wigen, 726 F. Supp. 389.

138. Quinn, 783 F.2d at 804,810 (concluding that the Castioni test needed modification because current struggles were no longer traditional).

139. Id.

140. Eain v. Wilkes, 641 F.2d 504, 507 (7th Cir. 1981). 
planted a bomb in a marketplace which killed two people and wounded thirty-six others. ${ }^{141}$ The Court of Appeals for the Seventh Circuit extended the political offense exception when it required: 1) the existence of war, revolution or civil strife; 2) an ideological motivation by the accused; 3 ) that the target is the state or its political structures; 4) that there be an existence of a link or nexus between the motive of the actor, and the target of the act. ${ }^{142}$ The court of appeals interpreted the uprising element relative to the need to meet the threat of terrorism, ${ }^{143}$ and noted, "[w]e recognize the validity and usefulness of the political offense exception, but it should be applied with great care lest our country become a social jungle and an encouragement to terrorists everywhere." 144

In addition to narrowing the uprising component, the court of appeals strictly construed the furtherance requirement, holding that unless a direct link exists "between the perpetrator, a political organization's political goals, and the specific act," that murder of innocent civilians cannot further the overthrow of a government. ${ }^{145}$ Because the defendant's alleged aim was to eliminate a segment of the civilian population in the occupied territory, the court held that a direct link did not exist. ${ }^{146}$ The Court of Appeals for the Seventh Circuit in Eain $v$. Wilkes appeared to be not so concerned with whether there was an uprising, as with whether the means employed by the accused involved indiscriminate violence against civilians. Extradition was granted where unnecessary violence was used and that the accused met the uprising and furtherance requirements became moot. ${ }^{147}$

The indiscriminate violence rationale was extended in the case of In re Doherty. ${ }^{148}$ Doherty's extradition was sought by Great Britain on murder and weapons possession charges stemming from participation in an attack on a British convoy in Northern Ireland. Doherty escaped to the United States from Northern Ireland while he was being held on charges that he murdered a British soldier. He and three other volunteers were ordered by an I.R.A. officer to ambush a convoy of five British officers. A British captain was killed and Doherty was jailed.

141. Id.

142. Id. at 518-521.

143. Id. at 520 .

144. Id.

145. Id. at 521.

146. Id.

147. Id.

148. In re Doherty, 599 F. Supp. 270, aff'd 786 F.2d 491. 
Two days before he was convicted, he escaped from prison. He was arrested by the FBI in New York in 1983. Judge Sprizzo of the Federal District Court in Manhattan ruled in 1984 that Doherty could not be extradited for a political offense, concluding that Northern Ireland was in a state of uprising and that Doherty had acted in furtherance of that uprising. ${ }^{149}$ The Court of Appeals for the Second Circuit affirmed the district court decision in 1986. ${ }^{150}$ In examining the Eain and Castioni requirements, the district court in Doherty examined whether the violence used was proportional to the political goal which was sought to be attained; ${ }^{151}$ otherwise, the Castioni "incidence test" could potentially be used to deny extradition of those responsible for events such as the Bataan death march and the Auschwitz murders. ${ }^{152}$ The court added to the political offense exception when it required, "[n]o act be regarded as political where the nature of the act is such as to be violative of international law, and inconsistent with international standards of civilized conduct." 153 In dictum the court in Doherty noted that he would have been extradited had he detonated a bomb in a civilian building. ${ }^{154}$ Doherty was not extradited. ${ }^{155}$

\section{c. Ahmad v. Wigen: A Violation of International Law Standard}

The indiscriminate violence limitation in Doherty parallels international law limitations observed by other courts. For example, international guidelines as to what would constitute an extraditable offense were used explicitly by the District Court for the Eastern District of New York in the case of In re the Extradition of Atta. ${ }^{156}$ Under an extradite

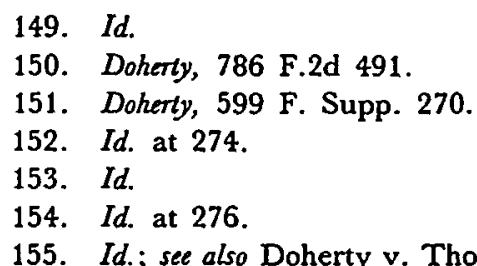
habeas corpus review dening Doherty's release from prison while the Board of Immigration Appeals processed him for possible deportation).

156. Alta, 706 F. Supp. 1032 (E.D.N.Y. 1989) (magistrate extradition hearings, held in December, 1987 and February, 1988 pursuant to 18 U.S.C. $\$ 3184$ ) (U.S. Attorney filed a second extradition complaint seeking de novo consideration, when an independent extradition hearing was held before U.S. district judge Edward Korman, sitting as an extradition magistrate); see also In re Extradition of Atta, No. 87-0551M, 1988 WL 66866 (WESTLAW) (E.D.N.Y. June 17, 1988) (denying extradition in June 1988 in part on the ground that the attack constituted a "political act" for which Ahmad was immune from extradition under the extradition treaty between the U.S. and Israel); see also The Convention on Extradition Between the Government of the 
or prosecute policy, the international guidelines examined by the court in Atta would have been used to determine whether or not the accused should be prosecuted by the United States under a theory of universal jurisdiction. Because Ahmad claimed that his offenses should be protected from extradition by the political offense exception and because his offenses were found to be violative of international law, he would have been prosecuted in the United States under an extradite or prosecute policy.

The district court in Ahmad on a habeas corpus review, in reversing a magistrate decision, applied the Doherty indiscriminate violence analysis ${ }^{157}$ and found that only acts which are not in violation of international law could qualify for the political offense exception. Because Ahmad's acts were indiscriminately directed against civilians and would be punishable even if committed by military personnel during wartime, he could not escape extradition under the exception. ${ }^{158}$ The Law of Armed Conflict was relied upon in order to limit the application of the political offense exception. ${ }^{159}$ Ahmad was required to prove that

U.S. and the Government of the State of Israel, Dec. 10, 1962, T.I.A.S. No. 5476 (hereinafter Convention on Extradition); Ahmad v. Wigen, 726 F. Supp 389 (E.D.N.Y. 1989) (granting the February 14, 1989 extradition request); see also Ahmad v. Wigen, 726 F. Supp. 389 (E.D.N.Y.) (By petition for writ of habeas corpus, Ahmad appealed the order claiming in part that he would face procedures and treatment in Israel "antipathetic to a court's sense of decency," which he claimed made him eligible for an evidentiary hearing on the due process issue. The District Court considered Ahmad's due process claim. The government sought a writ of mandamus from the Court of Appeals for the Second Circuit to prohibit the court from holding a hearing on the nature of the judicial procedures of Israel in an extradition matter, which the court of appeals denied. On September 26, 1989, the District Court denied Ahmad a political offense exception); see also Ahmad v. Wigen, 910 F.2d 1063 (2d Cir. 1990) (affirming the grant of extradition on August 10, 1990; see also Ahmad v. Wigen, 111 S.Ct. 23 (1990) (denying Ahmad's application for stay).

157. Ahmad v. Wigen, 726 F. Supp. 389, 402 (where the court heard testimony from a legal advisor for the State Department's Office of Combatting Terrorism who testified that "indiscriminate use of violence against civilian populations, innocent parties, is a prohibited act, and as such, is a common crime of murder, punishable in both [Israel and the United States]').

158. Id.; see also Atta, 706 F. Supp. at 1045-50 (shifting responsibility to the executive branch, although there is no explicit language in the treaty which would justify such a shift); see Convention on Extradition, supra note 77.

159. Ahmad v. Wigen, 726 F. Supp. 389 at 406 (this limitation would include Protocol I, which states in relevant part:

In order to ensure respect for and protection of the civilian population and civilian objects, the Parties to the conflict shall at all times distinguish between the civilian population and combatants and between civilian objects 
the offense was acceptable under conventions governing military conduct in the course of armed conflict. ${ }^{160}$ Stating that "[ $\left.t\right]$ he law has an obligation not to recognize such dark brutality under either the rules of war or of civilian insurrection or political opposition," 161 the District Court for the Eastern District of New York justified the "depolitization" 162 of the political offense exception through the Law of Armed Conflict limitation. A new standard was formulated in the district court's habeas corpus review in order to determine the extraditability of the accused, "[p]etitioner must show that: 1) there was a violent political disturbance of such a degree as to constitute in effect a state of civil war; 2) the acts charged were incidental to the disturbance; and 3) the acts did not violate the Law of Armed Conflict." 163 The district court reasoned that, " $[t]$ he current threat of terrorism to the peaceful expectations of civilians for a secure and safe society is so great as to either require some limitations on the political offense doctrine or an interpretation placing such offenses outside its protection." 164 The court in Ahmad chose the latter approach when it placed all of those offenses which are in violation of international law outside of the penumbra of the political offense exception. The decision in Ahmad demonstrates an American court's willingness to move away from the political offense exception.

Because the violent political offender is of international concern, standards of conduct defined by international agreement should be examined. However, an offense of political character, although violent, should be protected by the political offense exception against extradition. Violent political offenders found in the United States should be prosecuted by the United States, thereby guaranteeing due process, freedom

and military objectives and accordingly shall direct their operations only against military objectives.

(citing Protocol I, supra note 23 at 195) Protocol I has not been ratified by the United States).

160. Id.

161. Id. at 407.

162. The depoliticizing formula exempts certain offenses from the political offense exception by assuming a priori that they are common, rather than political crimes; see WIJNGAERT, supra note 4 at 133-34 (contending that "depoliticizing, while on the surface being a neutral statement, constitutes in fact the taking of a political position". Another formula is the "exception to the exception" which expressly derogates from the political offense exception by listing certain crimes, regardless of political intent, as outside of the political offense exception).

163. Ahmad v. Wigen, 726 F. Supp. at 408.

164. Id. at 403 . 
from prosecutorial persecution, preservation of the democratic principles embodied in the political offense exception, and protection of the world's innocent civilians.

\section{A Proposed Solution: United States Prosecution of the Violent Political Offender}

Many United Nations treaties emphasize the concept aut dedere aut judicare. ${ }^{165}$ Such treaties can create a legal duty to prosecute in circumstances where extradition is inappropriate and would require the United States to institute criminal proceedings against the offender. ${ }^{166}$ It may be said that prosecution of political offenders by the United States contradicts the spirit and intent of the political offense exception, and that political offenders from countries whose political systems are different from the United States do not pose a threat to United States political power. It may also be argued that prosecution will discourage political dissidents from taking real action against repressive governments. In terms of discouragement of the potential political offender if the United States adopts an extradite or prosecute policy, it has never been the position in any democratic government that political freedom be without boundary. ${ }^{167}$ United States domestic law does not afford political criminals freedom from the consequences of their acts. If they kill, they will be prosecuted for murder. Even nonviolent political offenders must suffer the legal consequences of their acts. It was not long ago that Martin Luther King, Jr. sat in a Birmingham jail for his political dissidence regarding civil rights or that Henry David Tho-

165. WiJNonerT, supta note 4, at 161-62:

[T] $T$ e treaties all follow the same general scheme: (a) in view of the alternative aut dedere, the crime in question is rendered extraditable; extradition remains subject to the domestic law of the requesting state which can, but need not necessarily apply the political offense exception; (b) in view of the alternative aut judicare, signatory states undertake to create, in their domestic legal order, jurisdiction with respect to the crimes concerned, by criminalizing them and by creating rules of competence which, according to the treaty, may amount to universal jurisdiction; if extradition is not granted, the requested state is obliged to undertake prosecutions or at least to submit the case to its competent authorities for purposes of prosecution.

For a definition of the principle of aut dedere aut judicare and an explanation of its legal origins, see Bassioun, supta note 4; see also WIJNoAgrt, supra note 4.

166. There is an issue as to whether international law is binding and enforceable by U.S. courts. See The Paquete Habana, 175 U.S. 677, 712 (1899) ("[t]he law of the United States includes international law").

167. See, J.S. Mill, supra note 39 at 370. 
reau was jailed for taking a political stand on the issue of unjust taxation. Consequently, the issue becomes one of how the United States will secure jurisdiction in order to prosecute violent political offenders found within its territory.

\section{A. Universal Jurisdiction Over the Violent Political Offender}

The principle of universal jurisdiction grants each nation jurisdiction over offenses which have been recognized as being of universal concern, regardless of the nationality of the offender or the country in which the offense occured. ${ }^{168}$ Although other types of jurisdiction require direct connections between the prosecuting state and the offense or the offender, universal jurisdiction allows every state to exercise jurisdiction in order to combat those heinous offenses which all states condemn. ${ }^{169}$ International treaties may subject terrorists to universal jurisdiction by the United States for such acts as hijacking and sabatoge of aircraft, ${ }^{170}$ hostage taking, ${ }^{171}$ crimes against internationally protected persons, ${ }^{172}$

168. O. Schachter, International Law in Theory and Practice 262 (1985).

169. See, L. Henkin, R. Pugh, O. Schachter \& H. Smit, International Law 823 (2d ed. 1987); see e.g., Tel-Oren v. Libyan Arab Republic, 726 F.2d 774, 781, 788 (D.C. Cir. 1984) (Edwards, J., concurring), cert. denied, 470 U.S. 1003 (1985); Filartiga v. Pena-Irala, 630 F.2d 876, 890 (2d Cir. 1980); Von Dardel v. Union of Soviet Socialist Republics, 623 F. Supp. 246, 254 (D.D.C. 1985) (relying on the "concept of extraordinary judicial jurisdiction over acts in violation of significant international standands ... embodied in the principle of 'universal' violations of international law"); In re Demjanjuk, 612 F. Supp. 544, 555 (N.D. Ohio 1985) (Israel's attempts to prosecute a concentration camp guard "conforms with the international law principle of 'universal jurisdiction"'), aff'd sub. nom., Demjanjuk v. Petrovsky, 776 F.2d 571 (6th Cir. 1985), cert. denied, 475 U.S. 1016 (1986); United States v. Layton, 509 F. Supp. 212, 223 (N.D. Cal. 1981) (recognizes universal jurisdiction as grounds to prosecute terrorist acts against internationally protected persons), appeal dismissed, 645 F.2d 681 (9th Cir.), cert. denied, 452 U.S. 972 (1981).

170. See, e.g., Convention for the Suppression of Unlawful Acts Against the Safety of Civil Aviation, Sept. 23, 1971 [hereinafter Aviation Convention), T.I.A.S. No. 7570 (entered into force Jan. 26, 1973), reprinted in 10 I.L.M. 133 (1971); Convention for the Suppression of Unlawful Seizure of Aircraft, Dec. 16, 1970, 22 U.S.T. 1641, T.I.A.S. No. 7192 (entered into force Oct. 14, 1971), reprinted in 10 I.L.M. 133 (1971).

171. International Convention Against the Taking of Hostages, Dec. 4, 1979 [hereinafter Hostage Convention], 18 I.L.M. 1456, adopted by G.A. Res 34/146, 34 U.N. GAOR Supp. (No. 39), U.N. Doc. A/C.6/34/L.23 (1979) (the United States is a party).

172. Convention on the Prevention and Punishment of Crimes Against Internationally Protected Persons, Including Diplomatic Agents, Dec. 14, 1973 (hereinafter Protected Persons Convention), 28 U.S.T. 1975, T.I.A.S. No. 8532, 1035 U.N.T.S. 167, adopted by G.A. Res. 3166, 27 U.N. GAOR Supp. (No. 10), U.N. Doc. A Res/3166 (1974) (the United States is a party); see also the Omnibus Diplomatic Security and Antiterrorism Act of 1986, Pub. L. No. 99- 399, s 1202, 100 Stat. 853, 896 (1986) (codified at 18 U.S.C. 5 2331). 
human rights violations through apartheid, ${ }^{179}$ and torture. ${ }^{174}$ Such treaties generally contain language which require parties to either extradite the offender or submit the offender's case to proper domestic authorities for purposes of prosecution. ${ }^{175}$

There is a question as to whether persons may be tried by the United States under a theory of universal jurisdiction if the conduct is not defined as being criminal by international treaty but is, rather, a violation of international customary law. An accused cannot be tried in federal court until the United States passes a statute defining the offense. ${ }^{176}$ Currently, four crimes are considered to be in violation of international customary law: piracy, slave trading, genocide, and war crimes. ${ }^{177}$ However, political offenses, by their very nature, may constitute war crimes. Political offenders should be held to the minimum requirement of Laws of Armed Conflict ${ }^{178}$ standard, which should minimize any objections to United States jurisdiction over the offenses. The United States must inculcate these crimes against customary international law into its own domestic criminal code.

Indeed, prosecution by the United States of another nation's political offenders may pose unique issues in terms of jurisdiction. However, the Act of State Doctrine may infringe on the exercise of universal jurisdiction by the United States because the doctrine suggests that an American court cannot examine acts which are committed by a foreign

173. Convention on the Suppression and Punishment of Apartheid, adopted Nov. 30, 1973, 1015 U.N.T.S. 243, adopted by G.A. Res. 3068, 28 U.N. GAOR Supp. (No. 30) at 75, U.N. Doc. A/Res/3068 (1973), reprinted in 13 I.L.M. 50 (1974) (the United States is not a party).

174. Convention Against Torture and Other Cruel, Inhuman or Degrading Treatment or Punishment, adopted Dec. 10, 1984 (hereinafter Torture Convention), adopted by G.A. Res. 39/46, U.N. GAOR Supp. (No. 51) at 197, U.N. Doc. Res/39/46 (1985), reprinted in 23 I.L.M. 1027 (1984) (the United States is not a party).

175. Hostage Convention, supre note 171, art. 8(1), at 1460; Torture Convention, art, 7(1), at 1032; Internationally Protected Persons Convention, supre note 172, art. 7, at 1981, T.I.A.S. No. 8532, at 1981; Aviation Convention, supra note 170, art. 7, at 571, T.I.A.S. No. 7570, at 571; for a discussion of the concept of universal jurisdiction, see K. Randall, Universal Jurisdiction Under International Law, 66 TEx. L. REv. 785 (1988) (arguing that adoption of multilateral conventions implies that the world community recognizes the legitimacy of universal jurisdiction).

176. See e.g., Dickinson, The Law of Nations as Part of the National Law of the United States, II, 101 U. Penn. L. Rev. 792, 795 (1953); Lillich, The Proper Role of Domestic Courts in the International Legal Order, 11 VA. J. InT'L L. 9, 16 (1970).

177. Kobrick, The Ex Post Facto Prohibition and the Exercise of Universal Jurisdiction over Intemational Crimes, 87 Colum. L. REv. 1515, 1529 (1987).

178. See Ahmad v. Wigen, 726 F. Supp. 389 (E.D.N.Y. 1989): 
sovereign. ${ }^{179}$ Such a doctrine may stifle United States jurisdiction over offenses to which another government's acts are central. The Act of State Doctrine may be raised by individuals whom the United States intends to prosecute. ${ }^{180}$ The Supreme Court preserved the role of the judiciary when the Act of State Doctrine was asserted as a defense in the case of Banco Nacional de Cuba v. Sabbatino:181

It should be apparent that the greater the degree of codification or consensus concerning a particular area of international law, the more appropriate it is for the judiciary to render decisions regarding it, since the courts can then focus on the application of an agreed principle to circumstances of fact rather than on the sensitive task of establishing a principle not consistent with the national interest or with international justice. ${ }^{182}$

Some acts of random violence and terrorism are codified by the international community as being against international law. Under an extradite or prosecute policy, individuals who commit such acts will not be shielded by the Act of State Doctrine.

Another doctrine which may affect United States jurisdiction over violent political offenders is that of forum non conveniens, wherein a violent political offender may claim that prosecution by the United States ignores the existence of a more convenient forum for the accused in the requesting state. ${ }^{183}$ The use of universal jurisdiction by the United States may "present special problems that bear on the fairness and propriety of the judicial proceedings in a State removed from the site of the crime and having no link of nationality to the accused." 184 The choice may become one as to the lesser of two evils: either violent political offenders will be extradited to the requesting nation or they may face prosecution by the United States. ${ }^{185}$ Political offenders prosecuted in the United States under an extradite or prosecute policy will be afforded more protection of basic juridical rights, because their acts will be subject to international scrutiny under the scope of international agreements.

179. See Legal Responses, supra note 1 at 104.

180. Id. at 105.

181. 376 U.S. 398 (1964).

182. Id. at 428 .

183. Legal. Responses, supra note 1 at 108-09.

184. O. Schachter, supra note 168 at 265.

185. See supra notes 71-96 and accompanying text for a discussion of the due process concerns. 


\section{B. International Law as a Threshold for Prosecution}

Under the proposed solution, the Ninth Circuit's neutrality standard ${ }^{186}$ will be the uniform standard by which potential political offenders are to be assessed in extradition proceedings. The neutral incidence test aligns itself with the political neutrality rationale, on which the political offense exception is based. ${ }^{187}$ The district court in Ahmad recognized the significance of the Ninth Circuit neutrality standard:

While seemingly harsh, there is something to be said for the traditional expansive view of the political offense, approved by the Ninth Circuit, in terms of modern conditions. It enables the courts to avoid such fuzzy issues as whether the "civilians" attacked were members of paramilitary forces. In the murky area of internal conflicts taking place all over the world, the roles of the various parties are often unclear. Courts may compound their difficulties in dealing with extradition by engaging in such inquiries. Moreover, foreign governments may find it easier to reach out to this country for assistance in returning those who oppose their policies in what are contended to be civil wars of liberation against dictatorial governments. To enforce extradition orders under such circumstances may implicate our courts in grave injustices and cruel repressions..$^{188}$

The political offense exception will be preserved and those who wish to instigate change against their governments, through both peaceful or nonpeaceful means, may escape persecution for their acts in the United States.

Political offenders who flee to the United States must not confuse an escape from political persecution with an escape from individual accountability, via prosecution in the United States. The dilemma lies with the violent political offender. It would be unjust and unsafe to allow the indiscriminately violent offender freedom for the sake of preserving the political offense exception. Rather than escape the dilemma through the creation of legal fiction which threatens the very

186. The territoriality limitation adopted by the Quinn court would not be applied. The Quinn neutrality test includes proof by the accused of an uprising and furtherance. Quinn v. Robinson, 783 F.2d at 810; see also infra note 188 and accompanying text for the Ahmad district court comments on the neutrality standard.

187. See supra note 43 and accompanying text for a discussion of the political neutrality rationale to the political offense exception.

188. Ahmad v. Wigen, 726 F. Supp. at 405 (E.D.N.Y. 1989). 
essence of the political offense exception, ${ }^{189}$ courts should determine whether the violence used in committing the offense warrants prosecution in the United States when assessing the violent political offender who has been spared extradition due to the political offense exception.

Two requirements must be met in order to establish a threshold for potential prosecution by an American court. First, the Seventh Circuit's indiscriminate violence limitation from Eain $v$. Wilkes will ensure that violence against the innocent does not go unpunished. ${ }^{190}$ The violation-of-international-law standard most likely will encompass any offense which may be prosecuted under the indiscriminate violence limitation test. The Ahmad-Doherty violation-of-international-law standard ${ }^{191}$ will provide objective guidelines in the determination of whether a political offender should stand trial in the United States for certain violent acts against humanity. Courts may look to treaties, international agreements, and to United States domestic laws in order to determine which crimes should be subject to prosecution by the United States.

\section{Conclusion}

Because there is a need for the international community to control acts of violence against innocent civilians, the United States has a duty to improve its handling of violent political offenders. By remaining politically neutral, United States courts may follow international treaties and domestic laws in determining whether an accused should stand trial for an offense. Rather than taking a Pontius Pilate approach, by completely washing its judicial hands of the political offenders, the United States, through prosecution of violent political offenders found in its territory, may preserve the democratic principles upon which the political offense was founded while at the same time preserving the peaceful expectations of the world's civilians. Ideally, other nations will follow the American example of extradite or prosecute and, even if they do not, violent offenders will be provided with one less safe haven in which to hide. Symbolically, prosecution of violent political offenders will represent a goal of universal peace which has yet to be achieved

189. See supra note 162 and accompanying text for a discussion of the "depolitization" and "exception to the exception" approaches.

190. 641 F.2d 504 (2d Cir. 1981); see supra notes $133-140$ and accompanying text for a discussion of the Eain indiscriminate violence limitation.

191. In re Doherty, 599 F. Supp. 270 (S.D.N.Y. 1984); Ahmad v. Wigen, 726 F. Supp. 389; see supra notes 148-164 and accompanying texts for a discussion of the violation-of-international-law standard. 
by the international community. Internalization of such a symbol by the United States and by the international community may lead to introspection by nations as to their own practices relative to acts of state terrorism and state sponsored violence. Ironically, such violence is normally directed at political dissidents of nation states. An extradite or prosecute policy may help to unlock the chains of circular political violence.

Sarah L. Nagy*

- J.D. candidate, 1992, Indiana University School of Law-Indianapolis. 
